Ruiz-Nava, M.P., Conejeros-Vargas, C.A., \& SolísMarín, A.A. (2021). Redescription of the sea urchin Eucidaris thouarsii (Cidaroida: Cidaridae) based on material from the Mexican Pacific. Revista de Biología Tropical, 69(S1), 438-451. DOI 10.15517/ rbt.v69iSuppl.1.46383

\title{
Redescription of the sea urchin Eucidaris thouarsii (Cidaroida: Cidaridae) based on material from the Mexican Pacific
}

\author{
Mariana P. Ruiz-Nava ${ }^{1 *}$ \\ Carlos A. Conejeros-Vargas ${ }^{2}$ \\ Francisco A. Solís-Marín ${ }^{3}$
}

1. Licenciatura en Biología, Facultad de Estudios Superiores Iztacala, Universidad Nacional Autónoma de México, Av. De Los Barrios 1, Hab. Los Reyes Ixtacala, Barrio de los Árboles, Tlalnepantla, Estado de México, México; mpaola.ruiznava@gmail.com (*Correspondence).

2. Posgrado en Ciencias del Mar y Limnología, Universidad Nacional Autónoma de México, Av. Ciudad Universitaria, Coyoacán, Ciudad de México, México; conejeros@ciencias.unam.mx

3. Colección Nacional de Equinodermos "Dra. Ma. Elena Caso Muñoz", Laboratorio de Sistemática y Ecología de Equinodermos, Instituto de Ciencias del Mar y Limnología, UNAM, Av. Ciudad Universitaria, Coyoacán, Ciudad de México, México; fasolis@cmarl.unam.mx

Received 15-VII-2020. Corrected 21-X-2020. Accepted 06-XI-2020.

\begin{abstract}
Introduction: Eucidaris thouarsii is a cidaroid sea urchin found from the Gulf of California to Ecuador. Its taxonomy is based on general descriptions of test shape, primary and secondary spines, the Aristotle's lantern, apical system, and peristome. Objective: To redescribe E. thouarsii with detailed descriptions, adding new taxonomic characters. Methods: We examined and reidentified 792 specimens, measuring and analyzing in detail structures of taxonomic value. Results: The horizontal diameter of the test ranges from 2.8 to 48.45 $\mathrm{mm}$; the peristome corresponds to $40-60 \%$ of that diameter, proportionally bigger than the apical system; the interambulacral areas are four times larger than the ambulacral areas. The variation of the pedicellariae is shown with scanning electron microscopy. The specimens of the Mexican oceanic islands are markedly different when compared to those of the mainland. Conclusions: Eucidaris thouarsii has five well differentiated secondary spines, and also specific regionalization; the apical system varies according to the size of the Horizontal Diameter of the Test; the globiferous pedicellariae have intraspecific differences; and the tridentate pedicellariae are specifically regionalized.
\end{abstract}

Key words: cidaroids; secondary spines; pedicellariae; morphology; taxonomy.

Historically, the genus Eucidaris has been recognized since Pomel's description in 1883, when he also proposed the division of the genus Cidaris Leske, 1778 due to the great number of species that it contained and the great variation in their morphological characters. The taxonomic character that he used to separate Eucidaris from the rest of its congeners was the presence of uncrenulated tubercles, in addition to the characteristics of the genus Cidaris (Leske, 1778). Latterly, Mortensen (1928) described the genus thus: organisms with short primary spines, of the same size as the horizontal diameter of the test (HDT); the primary spines sometimes are robust and thick, and the areolas are small and not sunken. The 
area occupied by the peristome is generally larger than the area corresponding to the apical system. It has large globiferous pedicellariae, without a terminal tooth in the valves, small globiferous pedicellariae without a terminal tooth, and tridentate pedicellariae. However, the constancy of forms in all genera makes the distinction between them and their species very difficult (Agassiz \& Desor, 1846), and the sum of small differences between the characters is needed for the identification of species.

Originally, only three species were included in the description of the genus Eucidaris; however, it possesses five living species: Eucidaris australiae Mortensen, 1950; E. galapagensis Döderlein, 1887; E. metularia (Lamarck, 1816); E. tribuloides (Lamarck, 1816) and E. thouarsii (Valenciennes in Agassiz \& Desor, 1846). According to Mortensen (1928), the genus dates back to the Miocene. Eucidaris is a pantropical genus: that is, its species are distributed in shallow waters $(<570$ $\mathrm{m})$, between the tropics and with an adjacent but not superimposed distribution (Lessios, Kessing, Robertosn, \& Paulay, 1996). The problems in identifying characters to diagnose the species within Eucidaris have given rise to confusion about the validity of E. galapagensis as a species, rather than as a variation of $E$. thouarsii, since the differences between them are discreet; nevertheless, molecular studies have shown that both species are valid (Lessios, Kessing, Robertosn, \& Paulay, 1999).

Eucidaris thouarsii was described by Valenciennes (L. Agassiz \& Desor, 1846) as follows: "...sea urchin with narrow ambulacral areas, made up of four lines of granules, whose two internal parts are barely developed. Tubercle base broad. Intermediate granules between the rows, narrow, quite apparent, not very tight. Sub-cylindrical spines, swollen, very granular...". As the description was made in 1846 and the genus Eucidaris was described in 1883, the original name of the species was Cidaris thouarsii; this is probably the reason for the historical taxonomic confusions within the genus Eucidaris. For example, Döderlein (1887) considered Eucidaris as a subgenus, and H.L. Clark (1907) described specimens using its original name (Cidaris thouarsii), without considering the existence of the genus Eucidaris.

The most exhaustive work on the description of the species is from Mortensen (1928), who was very meticulous in describing the arrangement of the interambulacral plates, the shape of the pedicellariae and the primary spines ornamentation. Just over twentyfive years later, Caso (1953) synonymized Hesperocidaris asteriscus H.L. Clark, 1948 with Eucidaris thouarsii, considering that the descriptions of both taxa were morphologically interconnected; however, in her doctoral thesis in 1961 she considered both species as valid.

Due to the different changes in the identification of diagnostic characters that Eucidaris thouarsii has undergone from its original description to the most recent studies, the aim of this paper is to redescribe this species, adding and distinguishing the main characters that facilitate the specific determination of specimens of E. thouarsii, and to provide an extended diagnosis for the species, including the variation of some characters on different sizes of them.

\section{MATERIALS AND METHODS}

A total of 792 specimens were analyzed using an OLYMPUS ${ }^{\circledR}$ SZX7 stereoscopic microscope. We followed the descriptions by Mortensen (1928) and Caso (1976) to properly identify the specimens; additionally, we reviewed the photographs of the material type available in the database of the Natural History Museum of Paris. The characters in table 1 were used to perform the specimen examination. Finally, 16 specimens were chosen (that were in good condition without apparent regeneration or fractures) and in which the details of the structures could be better observed and were photographed in the Laboratorio de Microscopia y Fotografia de la Biodiversidad of the Instituto de Biologia (IB-UNAM), with a Leica DFC490 multifocal microscope. The areas photographed were the peristome, the 
TABLE 1

Characters and abbreviations used to examine and redescribe Eucidaris thouarsii. Asterisk (*) indicates the characters that are described in detail herein

\begin{tabular}{|c|c|c|c|}
\hline Character & Abbreviation & Character & Abbreviation \\
\hline Test height & $\mathrm{TH}$ & Maximum length of the primary spine & MLPS \\
\hline Horizontal diameter of the test & HDT & Secondary spines* & $\mathrm{SP} *$ \\
\hline Peristome diameter & $\mathrm{PD}$ & Primary tubercles & PT \\
\hline Apical system diameter & ASD & Secondary tubercles & ST \\
\hline Coronal plates & $\mathrm{CP}$ & Interambulacral plates & IP \\
\hline Genital plates & GP & Ambulacral plates & AP \\
\hline Ocular plates & $\mathrm{OP}$ & Ambulacral pores & Apo \\
\hline Periproct plates* & PP* & Tube feet ossicles* & $\mathrm{TFO}^{*}$ \\
\hline Genital pores & GPo & Globiferous* pedicellariae & GPe* \\
\hline Madreporite & M & Tridentate* pedicellariae & $\mathrm{TP}^{*}$ \\
\hline
\end{tabular}

apical system, the ambulacral and inter-ambulatory areas, as well as the ornamentation of the primary spines and the different morphotypes of the secondary spines.

To identify the pedicellariae, specimens of different sizes were selected and preparations were made for Scanning Electron Microscopy (SEM) by extracting these structures from different areas (ambitus, peristome, apical system and below the lamellae). After a dehydration train with gradual alcohol changes $(70 \%, 80 \%$ and absolute), the samples were covered with ionized gold in the Laboratorio de Biodiversidad Animal II of the IB-UNAM, and the necessary photographs were taken to illustrate the most important characteristics and variations of the pedicellariae who were not described previously in other works.

For the morphometric analyses the following morphometric measurements were taken from each organism: height and width of the test, the length of the longest primary spine at the ambitus, the diameter of the peristome and the diameter of the apical system. All measurements were taken in millimeters with a TRUPER digital Vernier caliper. The measurements were taken in triplicate in each specimen to obtain an average of the individual sizes, and recorded in Microsoft Excel spreadsheet. We performed a linear regressions analysis using SigmaPlot14 in order to corroborate the correlation between the primary spine (at the level of the ambitus) and the horizontal diameter of the test, between the height of the test and the horizontal diameter of the test, and between the diameter of the peristome and the diameter of the apical system.

\section{RESULTS}

According to the bibliographic revision and the International Code of Zoological Nomenclature in the Chapter 11, Article 50, the taxonomic authority of Eucidaris thouarsii corresponds to Valenciennes, 1846, published in the work from L. Agassis \& Dessor "Catalogue raisonné des familles, des genres, et des espèces de la classe des échinodermes.". Knowing this, the correct way to cite this species is Eucidaris thouarsii (Valenciennes in L. Agassis and Dessor, 1846).

\section{Systematics:}

Order Cidaroida Claus, 1880

Superfamily Cidaroidea Gray, 1825

Family Cidaridae Gray, 1825

Subfamily Cidarinae Gray, 1825

Genus Eucidaris Pomel, 1883

\section{Eucidaris thouarsii}

(Valenciennes in L. Aggasiz \& Desor, 1846)

Eucidaris thouarsii (Valenciennes, 1846 in

L. Agassiz \& Desor, 1846) 
Cidaris thouarsii Valenciennes in L. Agassiz \& Desor, 1846: 326; A. Agassiz, 1863: 301; Agassiz, 1872-1874: 98-99, 213, 385-386; Lockington, 1875-1876: 152; H.L. Clark, 1902: 526; H.L. Clark, 1907: 185-186.

Cidaris (Eucidaris) thouarsii Döderlein, 1887: 18-20.

Eucidaris thouarsii H.L. Clark, 1913: 220; H.L. Clark, 1923: 157; H.L. Clark, 1940: 347; H.L. Clark, 1948: 226, 229-230; Mortensen, 1921: 22-24; Mortensen, 1928: 393-398; Boone, 1926: 8; Boone, 1933: 80-81; Ziesenhenne, 1937: 231; A.H. Clark, 1939: 12; A.H. Clark, 1946: 2; Caso, 1961: 222-226; Caso, 1962: 29; Birkeland, Mayer, Stames, \& Buford, 1975: 68; Maluf, 1988: 142; Conejeros-Vargas, 2015: 153-156.

Type material: Syntypes: National Museum of Natural History (Paris) MNHN-IE-2014-397, Galapagos Island; MNHN-IE-2013-10447, MNHN-IE-2013-10448, MNHNIE-2013-10449, MNHN-IE-2013-10450.

Type locality: California Noboux and Galapagos (H.L. Clark, 1948; Caso, 1978).

Distribution: Along the Mexican Pacific coast, the mainland islands and the Revillagigedo Archipelago.

Material examined*: Baja California Norte ICML-UNAM 4.3.82; ICML-UNAM 4.3.83; ICML-UNAM 4.3.84. Baja California Sur ICML-UNAM 4.3.1; ICML-UNAM 4.3.2; ICML-UNAM 4.3.14; ICML-UNAM 4.3.15; ICML-UNAM 4.3.16; ICML-UNAM 4.3.17; ICML-UNAM 4.3.18; ICML-UNAM 4.3.19; ICML-UNAM 4.3.21; ICML-UNAM 4.3.22; ICML-UNAM 4.3.26; ICML-UNAM 4.3.31; ICML-UNAM 4.3.77; ICML-UNAM 4.3.79; ICML-UNAM 4.3.80; ICML-UNAM 4.3.81; ICML-UNAM 4.3.95; ICML-UNAM 4.3.96; ICML-UNAM 4.3.100; ICMLUNAM 4.3.101; ICML-UNAM 4.3.102; ICML- UNAM 4.3.103; ICML-UNAM 4.1.6; ICML-UNAM 4.1.9; ICML-UNAM 4.1.22; ICML-UNAM 4.1.25; ICML-UNAM 4.1.26; ICML-UNAM 4.1.27; ICML-UNAM 4.1.61; ICML-UNAM 4.1.62; ICML-UNAM 10932 ICML-UNAM 10941; ICML-UNAM 10945; ICML-UNAM 10950; ICML-UNAM 10961;
ICML-UNAM 10964; ICML-UNAM 10967; ICML-UNAM 10970; ICML-UNAM 10974. Clarion Island ICML-UNAM 4.1.10. Clipperton Island ICML-UNAM 4.1.0. Colima ICML-UNAM 4.3.78; ICML-UNAM 4.3.88; ICML-UNAM 4.3.93; ICML-UNAM 4.3.94. Galapagos Islands ICML-UNAM 4.1.1. Guerrero ICML-UNAM 4.3.3; ICML-UNAM 4.3.4; ICML-UNAM 4.3.5; ICML-UNAM 4.3.6; ICML-UNAM 4.3.7; ICML-UNAM 4.3.12; ICML-UNAM 4.3.13; ICML-UNAM 4.3.20; ICML-UNAM 4.3.23; ICML-UNAM 4.3.24; ICML-UNAM 4.3.27; ICML-UNAM 4.3.86; ICML-UNAM 4.3.86; ICML-UNAM 4.3.104; ICML-UNAM 4.1.41; ICML-UNAM 4.1.7; ICML-UNAM 4.1.28; ICML-UNAM 4.1.16; ICML-UNAM 4.1.17; ICML-UNAM 4.1.18; ICML-UNAM 10667. Jalisco ICMLUNAM 4.3.0; ICML UNAM 4.3.8. Michoacán ICML-UNAM 4.3.67; ICML-UNAM 4.3.87; ICML-UNAM 4.3.89; ICML-UNAM 4.3.90; ICML-UNAM 4.3.9; ICML-UNAM 4.3.92; ICML-UNAM 4.3.105; ICML-UNAM 4.3.106; ICML-UNAM 4.3.107; ICML-UNAM 4.3.108; ICML-UNAM 4.3.109; ICML-UNAM 4.3.110; ICML-UNAM 4.1.13; ICML-UNAM 4.1.23; ICML-UNAM 4.1.24; ICML-UNAM 4.1.29; ICML-UNAM 4.1.36; ICML-UNAM 4.1.37; ICML-UNAM 4.1.38; ICML-UNAM 4.1.39; ICML-UNAM 4.1.40; ICML-UNAM 4.1.50; ICML-UNAM 4.1.51; ICML-UNAM 4.1.52; ICML-UNAM 4.1.53; ICML-UNAM 10593; ICML-UNAM 4.1.30; ICML-UNAM 4.1.31; ICML-UNAM 4.1.32; ICML-UNAM 4.1.33; ICML-UNAM 4.1.34; ICML-UNAM 4.1.35; ICML-UNAM 4.1.46; ICML-UNAM 4.1.47; ICML-UNAM 4.1.48; ICML-UNAM 4.1.49; ICML-UNAM 9943; ICML-UNAM 9967; ICML-UNAM 10063; ICML-UNAM 10087; ICML-UNAM 10105; ICML-UNAM 10122; ICML-UNAM 10136; ICML-UNAM 10157. Nayarit ICML-UNAM 4.3.97; ICML-UNAM 4.3.98. ICML-UNAM 4.1.19; ICML-UNAM 4.1.20; ICML-UNAM 4.1.21; ICML-UNAM 10031. Oaxaca ICML-UNAM 4.3.85; ICMLUNAM 4.3.99. Revillagigedo Archipelago ICML-UNAM 4.3.9; ICML-UNAM 4.3.10; ICML-UNAM 4.1.2; ICML-UNAM 4.1.3; 
ICML-UNAM 4.1.4; ICML-UNAM 4.1.5; ICML-UNAM 4.1.8; ICML-UNAM 4.1.11; ICML-UNAM 4.1.12; ICML-UNAM 4.1.15; ICML-UNAM 4.1.54; ICML-UNAM 4.1.55 ICML-UNAM 4.1.56; ICML-UNAM 4.1.57; ICML-UNAM 4.1.58; ICML-UNAM 4.1.59; ICML-UNAM 4.1.60; ICML-UNAM 18369; ICML-UNAM 18370; ICML-UNAM 18371. Sinaloa ICML-UNAM 4.3.29; ICML-UNAM 4.3.30; ICML-UNAM 4.3.32; ICML-UNAM 4.3.33; ICML-UNAM 4.3.34; ICML-UNAM 4.3.35; ICML-UNAM 4.3.36; ICML-UNAM 4.3.37; ICML-UNAM 4.3.38; ICML-UNAM 4.3.39; ICML-UNAM 4.3.40; ICML-UNAM 4.3.41; ICML-UNAM 4.3.42; ICML-UNAM 4.3.43; ICML-UNAM 4.3.44; ICML-UNAM 4.3.45; ICML-UNAM 4.3.46; ICML-UNAM 4.3.47; ICML-UNAM 4.3.48; ICML-UNAM 4.3.49; ICML-UNAM 4.3.50; ICML-UNAM 4.3.51; ICML-UNAM 4.3.52; ICML-UNAM 4.3.53; ICML-UNAM 4.3.54; ICML-UNAM 4.3.55; ICML-UNAM 4.3.56; ICML-UNAM 4.3.57; ICML-UNAM 4.3.58; ICML-UNAM 4.3.59; ICML-UNAM 4.3.60; ICML-UNAM 4.3.61; ICML-UNAM 4.3.62; ICML-UNAM 4.3.63; ICML-UNAM 4.3.64; ICML-UNAM 4.3.65; ICML-UNAM 4.3.66; ICML-UNAM 4.3.68; ICML-UNAM 4.3.69; ICML-UNAM 4.3.70; ICML-UNAM 4.3.71; ICML-UNAM 4.3.72; ICML-UNAM 4.3.73; ICML-UNAM 4.3.74; ICML-UNAM 4.3.75; ICML-UNAM 4.3.76; ICML-UNAM 4.3.11; ICML-UNAM 4.1.45. Sonora ICML-UNAM 4.3.25; ICMLUNAM 4.3.28; ICML-UNAM 4.1.42; ICMLUNAM 4.1.43; ICML-UNAM 4.1.44.

*Note: the material is sorted by location.

Diagnosis (modified from Mortensen, 1928): Robust, relatively short primary spines with blunt or truncated distal ends, rough ornamentation. Secondary spines of five different type well defined and regionalized. Two types of pedicellariae: large abundant globiferous, small globiferous with long peduncle and terminal teeth, and tridentate pedicellariae. Plates of apical system covered with tubercles. Interambulacral tubercles arranged in regular series, adradially to them each plate has a secondary tubercle. Ambulacral pores of approximately same size.

Redescription: The test is wider than tall, with the oral and aboral poles depressed; their sizes range from 2.8 to $48.45 \mathrm{~mm}$ in the Horizontal Diameter of the Test (HDT); the peristome membrane extends beyond the level of the test, with this feature visible even in the specimens of smaller sizes $(2.88 \mathrm{~mm})$ (Fig. 1A, $1 \mathrm{~B}, 1 \mathrm{C}, 1 \mathrm{D}, 1 \mathrm{E}, 1 \mathrm{~F})$. The ambulacral areas are composed of two parallel rows of ambulacral plates, each consisting of a pair of ambulacral pores, a secondary tubercle, and milliary tubercles. The interambulacral areas are four times larger than the ambulacral areas, made up of two rows of four to nine coronal plates, each one with one areole and a hemispherical mamelon with a perforation in the center; around the areole there are a series of ST and milliary tubercles continuing in the direction of the interradial zone (Fig. 1G1H, 1I, 1J).

The peristome ranges from 40 to $66 \%$ of the HDT (proportionally bigger compared to the apical system diameter) and is covered by a membrane with irregular plates in the interambulacral areas, ornamented by a series of two or three tubercles where secondary spines are inserted, and globiferous pedicellariae; the two rows of AP overlap as they approach the oral opening (Fig. 2A, 2B, 2C, 2E, 2F). The apical system is composed of several small periproctal plates around the anal pore and ten large peripheral plates covered by milliary tubercles, five corresponding to the genital plates (one of them corresponds to the madreporite) and five to the ocular plates; the arrangement of the genital plates results in a star shape (Fig. $2 \mathrm{G})$. The ocular plates are triangular, elongated with a perforation in the center of the base, almost on the groove; they connect at their base with the ambulacral area and on the sides with the genital plate (GP). The genital plates are trapezoid, longer than wide with the variation in this character shown in the different sizes of this species: in the smallest organisms (sizes 2.8 to $14 \mathrm{~mm}$ ) (Fig. $2 \mathrm{H}, 2 \mathrm{I}$ ) the plates are slightly triangular; as test size increases, it 


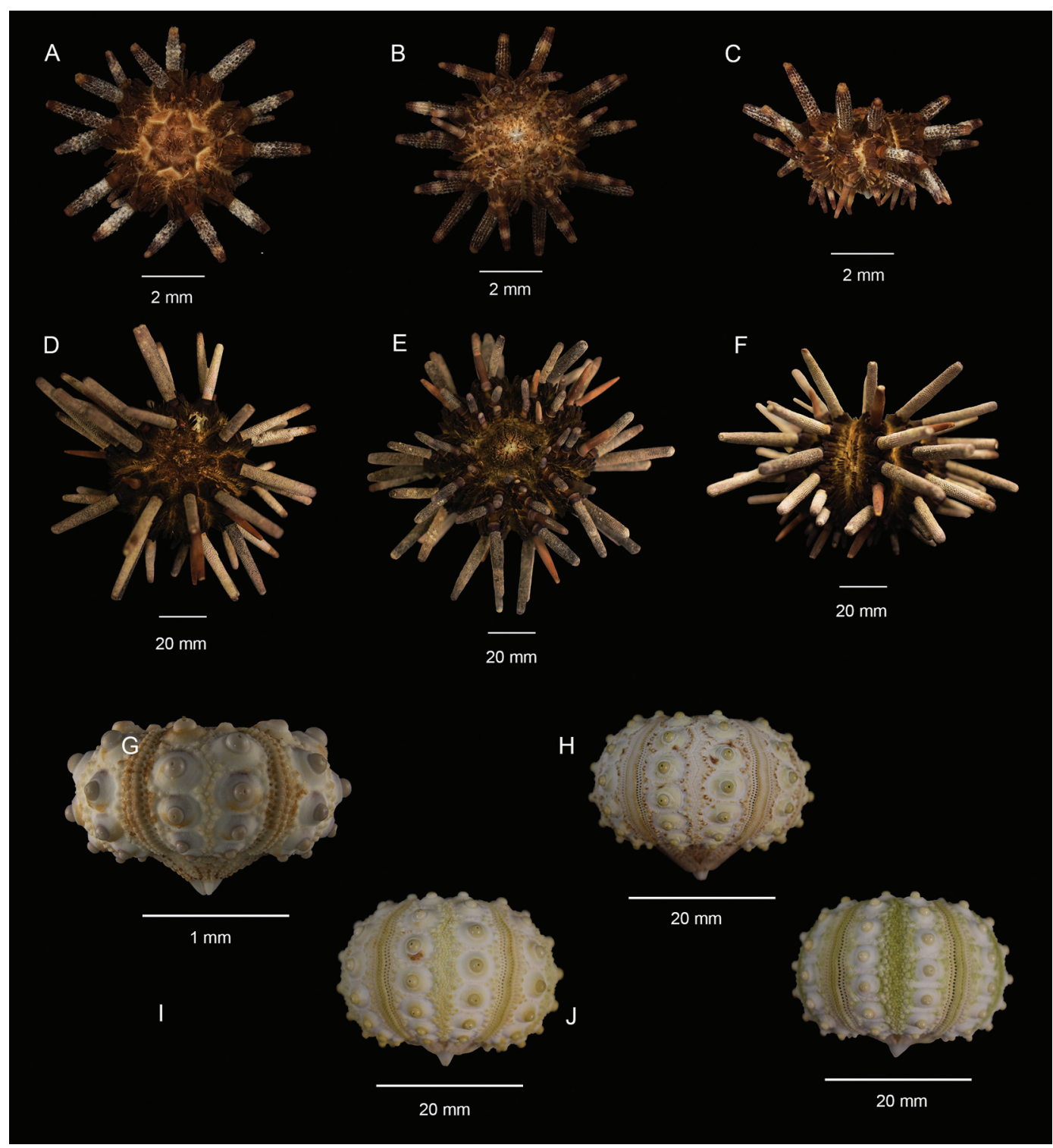

Fig. 1. Size variations of Eucidaris thouarsii. A, D. Apical view. B, E. Oral view. C, F. Lateral view. G-H. Lateral view from naked tests, showing the arrangement of the ambulacral and the interambulacral areas. A-C, G ICML-UNAM 4.3.80; D-F ICML-UNAM 4.3.105; H ICML- UNAM 4.3.19; I ICML-UNAM 4.3.33; J ICML-UNAM 4.3.28.

can be seen that the plates lose the upper angle, resulting in truncated GP in large specimens (> $30 \mathrm{~mm}$ ) (Fig. 2J, 2K, 2L), acquiring the trapezoid shape. The genital perforation, normally in the center of the plate, can sometimes be very close to the distal edge; in the genital perforations a series of SP is found covering the genital pores. The madreporite, the largest genital plate, is distinguished by being covered with small perforations; in some cases, it is bulky and occasionally moves the arrangement of the apical system. The grooves between ocular plates and genital plates are very evident in small specimens (from 2.88 to $13 \mathrm{~mm}$ ), but in 
the larger ones $(<13 \mathrm{~mm})$ the grooves are thin, difficult to distinguish with the naked eye, and covered by a dense layer of secondary spines. The periproctal plates near the base of the genital plates are pentagonal and those next to the anus are quadrangular.

The primary spines at the level of the ambitus are semi-cylindrical, narrow at their base, the same size or slightly shorter than the HDT; they are composed of four parts: the necklace, the milliary ring, the shaft and the crown. The milliary ring is less than $1 \mathrm{~mm}$ tall and composed of a series of longitudinal ridges; the axis of the spine is ornamented by irregular semi-spherical tubercles that run in rows towards the distal part - as they approach the terminal part of the spine the tubercles are elongated, forming ridges that result in a terminal crown, the number of ridges not being directly related to the size of the specimen. The terminal crown is only visible in the most conserved spines and agglomerations of granules or ridges can be seen in the center of the crown in the direction of the base of the spine. The secondary spines (SP) can be divided into five morphs as follows, specifically located on the test:

[1] Lamellae; are the largest secondary spines $(5 \mathrm{~mm})$, characterized by being semirectangular, with rounded tips; shortly before the terminal part there is a slight crescentshaped depression, resulting in a spatula shape (Fig. 3A). This type is found around the areolas, in the secondary tubercles, thus forming a protective barrier for the insertion area of the primary spines. Next to the lamellae, towards the interradial suture is the second morph, [2] smaller (between 2 and $3 \mathrm{~mm}$ in length), robust and wider towards the distal part (Fig. 3B). Interspersed with this is the third morph, [3] semi-rhomboid, and two sizes (from 1 to $1.5 \mathrm{~mm})$, the smallest bordering the interradial suture (Fig. 3C). These spines are also arranged on the surface of all the plates of the apical system on milliary tubercles, the largest in two specific areas: on the genital plates around the pores and covering them; and bordering all the plates. The former is more evident at the edge of the entire apical system. The fourth morph [4] is located one per ambulacral plate in the terminal part thereof; they are thin, almost as tall as the second morph ( 2 to $2.5 \mathrm{~mm}$ ), rectangular in shape and located in two parallel rows (Fig. 3D). In the membrane of the peristome there are elongated, irregular plates where the fifth morph [5] is inserted: they are elongated and thin with a wide and spatulate tip, and completely cover the surface of the plates of the peristome membrane; their height ranges from 2 to $2.5 \mathrm{~mm}$ (Fig. 3E).

There are globiferous and tridentate pedicellariae. The globiferous pedicellariae are of two different morphs, their sizes ranging from 1 to $3 \mathrm{~mm}$ and it is possible to distinguish them by the size of the stem and the valves. The first type has a thin stem, with the insertion of the neck into the stem being found in the center of the axis, or displaced (Fig. 4B, 4C). In general, the valves are wide at their base and narrow towards the distal region (triangular shape); from dorsal view, three parts can be observed, the intermediate one being smooth until it reaches the distal end, where the terminal tooth can be seen, while the parts that correspond to the left and right edges of the tooth are perforated (Fig. 4C). From ventral view, the articular zone is located in the proximal part, where a semicircular base that can be reduced or as wide as the width of the articular zone can be observed; in this part there are also two to three lateral edges. The valve is divided in half by the apophysis, which rises above the edge of the valve, and can run to the middle or three quarters of the inner face; on the rest of the surface small perforations continue towards the edges. In the distal part, a triangle is formed that at its base has two teeth higher and sharper than the rest, one for vertex $\mathrm{A}$ and $\mathrm{B}$; in $\mathrm{C}$ the terminal tooth is in the form of a hook with a blunt or claw-like tip, although within the variations, the tooth can be separated from this triangular formation. The periphery of the valve is serrated; in the proximal part the teeth are short and as the distal area approaches, they are more evident (Fig 4E, 4F). There are two other variations within this first type of pedicellariae. 


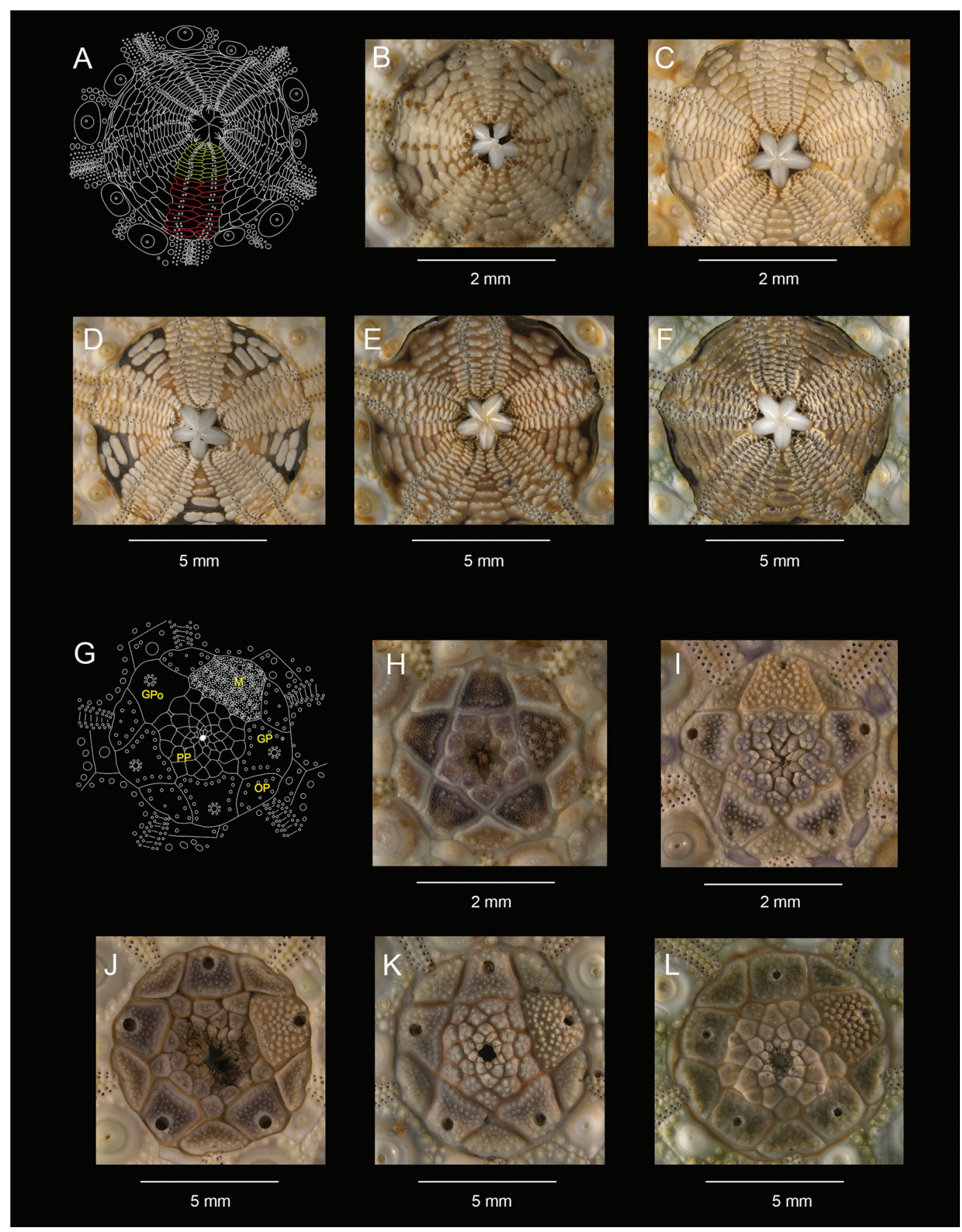

Fig 2. Arrangement of the peristome and the apical system. A. Diagram of the ambulacral plates on the peristome membrane in yellow and the overlapping ambulacral plates in red. B-F. Shows the changes present on different sizes. G. Diagram of the apical system. Abbreviations. M. Madreporite, GP. Genital plate, OP. Ocular plate, PP. Periproctal plate. GPo. Genital pore. H-I. From specimens of sizes 2.8 to $14 \mathrm{~mm}$ (HDT). J-L. From specimens larger than $30 \mathrm{~mm}$ (HDT). B. ICML-UNAM 4.3.101; C. ICML-UNAM 4.3.27; D. ICML-UNAM 4.1.36; E. ICML-UNAM 4.1.51; F-L. ICML-UNAM 4.1.41; G. ICMLUNAM 4.3.19; H.ICML-UNAM 4.1.46; I. ICML-UNAM 4.1.50; J.ICML-UNAM 4.3.89; K. ICML-UNAM 4.3.108. 


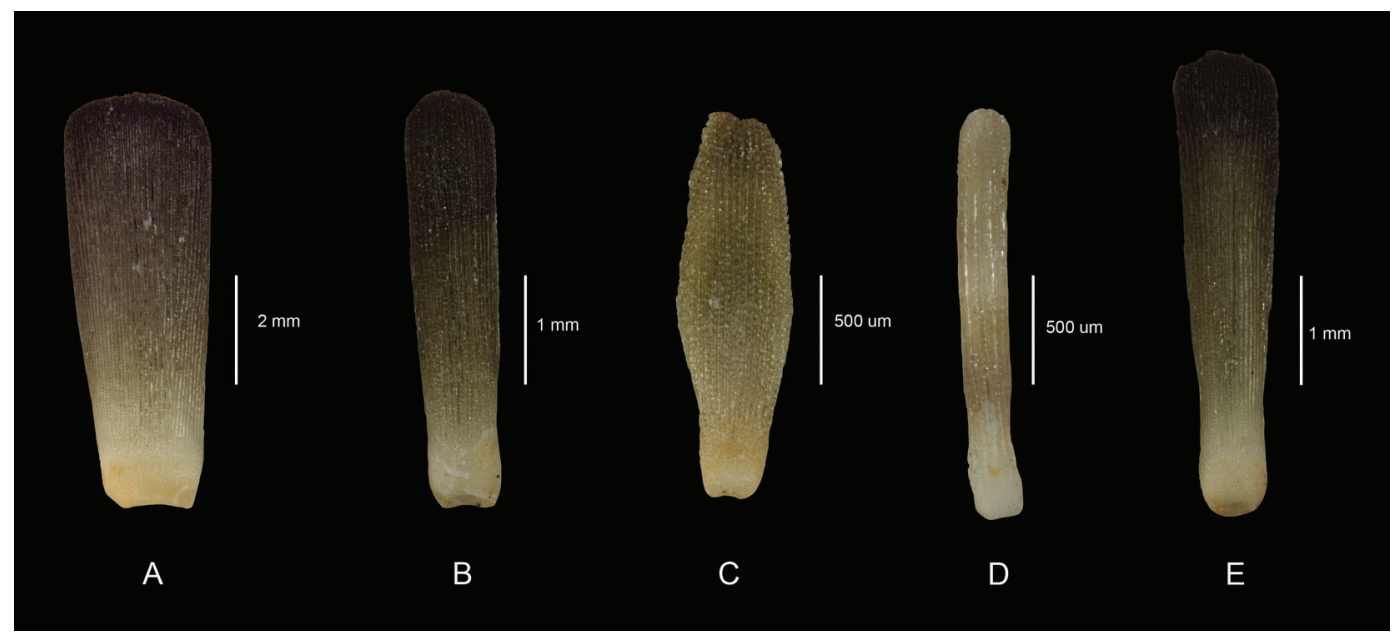

Fig. 3. Secondary spines. A. lamellae, located around the areolae. B. smaller than the lamellae, in the interradial suture. C. semi rhomboid shape, bordering the interradial suture. D. the thinner spines, in the ambulacral plates. E. located in the peristome. A-E. ICML-UNAM 4.3.5.

Firstly, sharper peripheral teeth from the middle of the valve to the distal area; in the terminal part it is not possible to distinguish a consistent triangle, nor is there a terminal tooth; the shape of the valve is more elongated, and the articular zone is continuous to the striae of the insertion zone (Fig. 4G). Secondly, the periphery of the valve towards the terminal part is interrupted, forming a slight fan that returns to its original line (Fig. 4H). The second form of globigerous pedicellariae corresponds to those with the thickest stem with robust valves covered by a brown pigmented epithelium; in the external view only complete perforations of half of the valve to the distal area can be observed on the lateral parts, while in the rest of the body of the valve there are very small perforations and some superficial ones; before the terminal part, the valve becomes slender. In the internal view of the valve, the same structures differentiated in size can be found, and the insertion zone is continuous along the width of the base. In the lateral view, the process is higher towards the middle part of the valve, the teeth are small and sharp at the periphery, while those that are arranged on the terminal area are larger (Fig. $4 \mathrm{I}, 4 \mathrm{~J}, 4 \mathrm{~K})$. Regarding its regionalization, this type of pedicellariae is distributed at the apical system, peristome, ambulacral areas and in the interradial suture; the pedicellariae covered by epithelium are located towards the membrane of the peristome and at the edges of the apical system. The valves of the tridentate pedicellariae are approximately $1 \mathrm{~mm}$ long, with a long and thin stem; the neck is located in the center of the stem, and the valves become thinner towards the distal part. In the external view, the valves are smooth where the lateral perforations are barely visible; in the internal view, the insertion base is semicircular, with continuous irregularly shaped grooves stacked, forming a cusp that covers the first fifth part of the valve (Fig 5L). At the base of the valve two protrusions can be seen on each side; on the periphery of the structure very small and irregular teeth can be found. Its distribution over the organism is limited, between the muscle fibers of the primary spines and the lamellae that cover them.

The ambulacral tube feet are also of two types and are regionalized on the surface of the test: in the section corresponding to the ambitus-peristome they are of robust body and with a suction disc in the terminal part; in the ambitus-apical system area, the tube feet are of a finger-like type, without suction disc. There are 


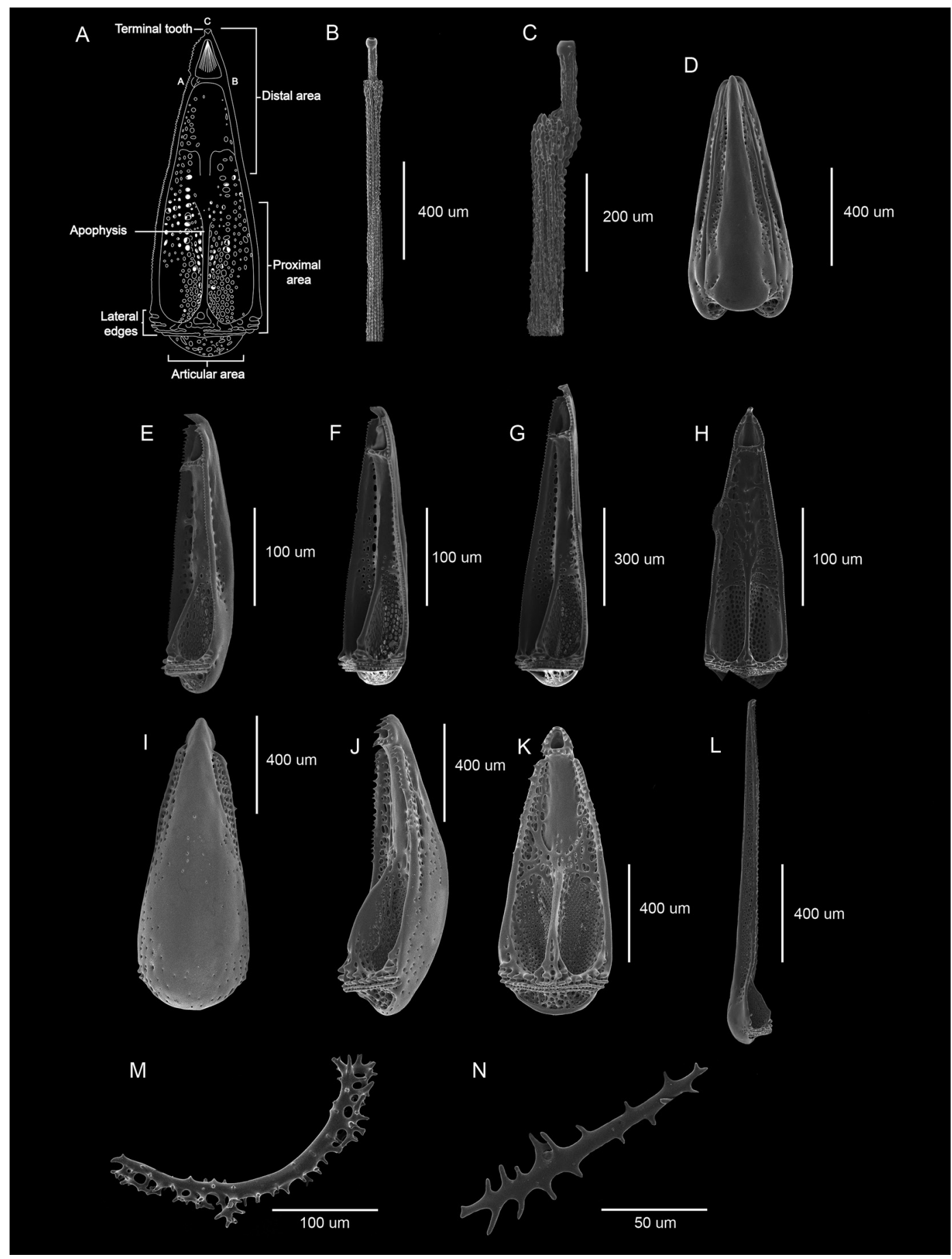

Fig. 4. Pedicellariae present in Eucidaris thouarsii. A. Diagram with the parts that compose-the valves of a globiferous pedicellaria. B-C. Globiferous pedicellariae stems. D-K. Globiferous pedicellariae. L. Valve of tridentate pedicellariae. M-N. Tubefeet osscicles. 


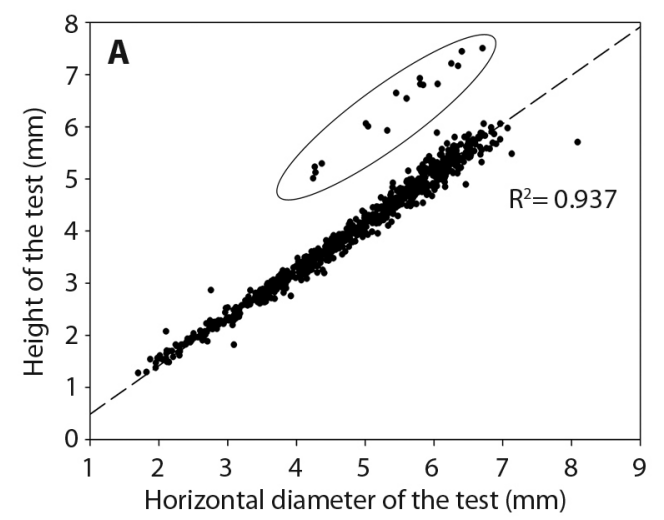

Fig. 5. Morphometric analyses of the relationship between characters. A. HDT-Height of the test. B. HDT- Maximum length of the primary spine. C. Peristome diameter-Apical system diameter.
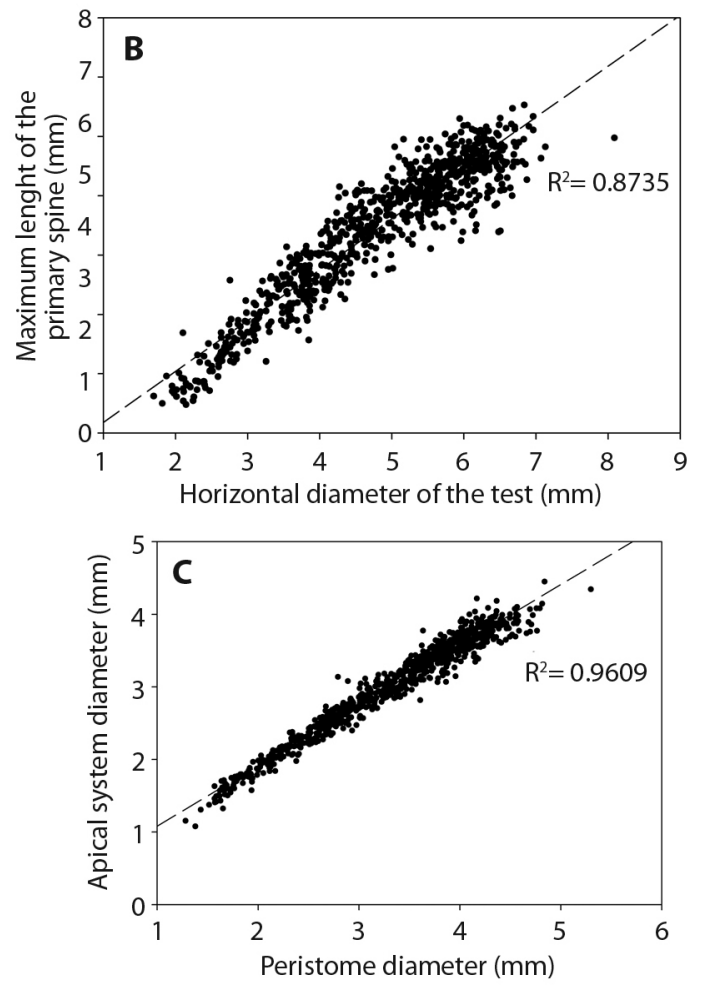

DISCUSSION

A total of 20 morphological characters were analyzed, 15 of which had been previously reported (Döderlein, 1887; Mortensen, 1928 ) and five of which (periproct plates, secondary spines, tube feet ossicles, globiferous pedicellariae and tridentate pedicellariae) are new proposals to diagnose Eucidaris thouarsii morphologically. In addition, it has been demonstrated that, while mainland specimens show variations in the apical system according to the HDT, oceanic island specimens show variations in the other characters that were exmained in this study as well. Many of the previous taxonomical descriptions (Agassiz \& Desor, 1846; Döderlein, 1887; Clark, 1907; Mortensen, 1928) were made using a single or few specimens (2-5), where a slightly 
different character was often pointed out as the basis for new species or variety description, without considering the intraspecific variation. The species of the genus Eucidaris are distinguished by having cylindrical primary spines that are the same size or shorter than the horizontal diameter of the test, as well as having globiferous pedicellariae. In this redescription of E. thouarsii, we present a better and more explicit diagnosis, because although in the description of E. tribuloides (sister species from the Gulf of Mexico) it is mentioned that the interporiferous areas are narrow and the color of the species is distinct, it is important to point out that the addition of specific measurements in the descriptions allows us to be much clearer when identifying species.

Mortensen (1928) mentioned that the shape of the primary spines lacks taxonomical validity when distinguishing cidaroid taxa; nonetheless, H.L Clark (1913) and Caso (1978) utilized the number of coronal crests to distinguish Eucidaris thouarsii from Hesperocidaris asteriscus. We agree with Mortensen (1928) in rejecting this character because it is not constant in all the primary spines at the ambit level of one organism; these differences may be due to regeneration or probably associated with ontogenetic growth or size of the specimens (Ebert, 1988).

Although Mortensen (1928) mentioned the presence of different morphotypes of secondary spines; in this paper we describe five different types of secondary spines and their specific regionalization, which are present in all sizes of the specimens analyzed. This suggests that such characters do not have variations related with the species itself, nor to the ontogeny of it.

Among the works that describe E. thouarsii, the work of Döderlein (1887) stands out, where he states that within the characters to clearly identify E. thouarsii is the height and horizontal diameter of the test (possible correlation between both measures to reaffirm its hemispherical shape); this was verified through linear regression (Fig. 5A), resulting in a positive correlation $\left(\mathrm{R}^{2}=0.937\right)$ between HDT and the height of the test. In this study a clear separation of the specimens belonging to the oceanic islands (Clipperton and Revillagigedo archipelago) can be differentiated when comparing them with the mainland organisms (Fig. 5A, data inside the ellipse), indicating that the specimens belonging to the oceanic islands are bigger and more spherical compared to the continental specimens, that are smaller and more flattened. The morphological variations identified in the oceanic island organisms could represent a new species; something similar happened with the E. thouarsii specimens from the Ecuadorian coast and from the Galapagos Islands that were later identified as Eucidaris galapagensis.

Döderlein (1887) provided valuable information regarding the apical system of the species, proposing the shape of the apical system plates as a diagnostic character and emphasizing the triangular shape of the genital and ocular plates. In this paper we identified this character only in the specimens ranging from 4.88 to $10 \mathrm{~mm}$ in horizontal diameter. As the diameter of the test increases, the genital plates change with it, being trapezoidal, or even quadrangular (Fig. 3) when the specimens are larger (> $40 \mathrm{~mm}$ ); Döderlein's idea works only for small specimens $(<20 \mathrm{~mm})$.

Coppard, Kroh and Smith (2012) suggested that tridentated pedicellariae are associated with cleaning functions in the organism. E. thouarsii possess tridentate pedicellariae only below the lamellae and above the muscle fibers of the primary spines. Coppard et al. (2012) suggest that the particular location of this pedicellariae is due to the fact that it is the space where the muscle and collagen fibers that give mobility to the primary spines are located; pedicellariae keep this area free of any external agent that could impede the mobility of such structures.

Further investigations regarding the morphological variation of $E$. thouarsii from oceanic islands need to be done in order to test if its molecular composition and ecology differs from those of mainland specimens. It is necessary to study the morphological variation of pedicellariae within the family Cidaridae, in 
order to corroborate its validity as a diagnostic character to distinguish between genera.

Ethical statement: authors declare that they all agree with this publication and made significant contributions; that there is no conflict of interest of any kind; and that we followed all pertinent ethical and legal procedures and requirements. All financial sources are fully and clearly stated in the acknowledgements section. A signed document has been filed in the journal archives.

\section{ACKNOWLEDGMENTS}

We would like to thank Alicia Durán (ICML, UNAM) for her technical support. To Susana Guzmán Gómez (IB, UNAM) for her technical support with the multifocal photography. To Berenit Garfias (IB, UNAM) for her technical support with the Scanning Electron Microscopy. CACV (scholarship holder 666781) thanks the National Council for Science and Technology (CONACyT) for the doctoral scholarship 722925. Finally, the authors would like to thank Matthew Lovegrove, Andrea Caballero-Ochoa and Luis E. Flores for the valuable comments when reviewing the English version of this manuscript.

\section{RESUMEN}

\section{Redescripción del erizo de mar Eucidaris thyarsii (Cidaroida: Cidaridae) basado en material del Pacífico mexicano}

Introducción: Eucidaris thouarsii es una especie de erizo de mar, cidárido presente desde el Golfo de California hasta Ecuador. Su taxonomía está basada en descripciones generales de la forma de la testa, espinas primarias y secundarias, la linterna de Aristóteles, el sistema apical y peristoma. Objetivo: Redescribir E. thouarsii con descripciones detalladas, añadiendo nuevos caracteres taxonómicos. Método: Examinamos y reidentificamos 792 ejemplares, midiendo y analizando a detalle estructuras de valor taxonómico. Resultados: El diámetro horizontal de la testa va de 2.8 a $48 \mathrm{~mm}$; el peristoma corresponde entre el $40-60 \%$ del diámetro horizontal de la testa, proporcionalmente más grande que el sistema apical; el área interambulacral es cuatro veces más grande que el área ambulacral. La variación en los pedicelarios se muestra con microscopía electrónica de barrido. Los ejemplares de las islas oceánicas mexicanas son claramente diferentes, comparados con los de la costa. Conclusiones: Eucidaris thouarsii tiene cinco tipos bien definidos de espinas secundarias que se encuentran regionalizadas en la testa, el sistema apical varía de acuerdo con el diámetro horizontal de la testa, los pedicelarios globíferos tienen diferencias intraespecíficas y los pedicelarios tridentados estas específicamente regionalizados.

Palabras clave: cidáridos; morfología; pedicelarios; morfología, taxonomía.

\section{REFERENCES}

Agassiz, A. (1863). List of the Echinoderms sent to different Institutions in exchange for other specimens, with annotations. Bulletin of the Museum of Comparative Zoology Cambridge, Massachusetts, 1(2), 17-28.

Agassiz, A. (1872-1874). Revision of the Echini. Memoirs Museum of Comparative Zoology at Harvard College, 3(1-4), 1-744.

Agassiz, L., \& Desor, P.J.E. (1846). Catalogue raisonné des familles, des genres, et des espèces de la classe des échinodermes. Annales des Sciences Naturelles, Troisième Série, Zoologie, 6, 305-374.

Birkeland, C., Mayer, D.L., Stames, J.P., \& Buford, C.L. (1975). Sublitoral communities of Malpelo Island. Smithsonian Contributons to Zoology, 175, 55-58.

Boone, L. (1926). Echinoderms from the Gulf of California and the Perlas Islands: Scientific Results of the Second Oceanographic Expedition of the "Pawnee". Bulletin of the Bingham Oceanographic Collection, 2(6), 1-14.

Boone, L. (1933). Scientific results of the cruises of the yachts "Eagle" and "Alva", 1921- 1928, William K. Vanderbit, Commanding. Coelenterata, Echinodermata and Mollusca. Bulletin of the Vanderbilt Marine Museum. Huntington, 4, 1-217.

Caso, M.E. (1953). Estado actual de los conocimientos acerca de la fauna de los equinodermos de México. México: Memoria del Congreso Científico Mexicano, Universidad Nacional Autónoma de México.

Caso, M.E. (1961). Estado actual de los conocimientos acerca de equinodermos de México (Doctoral thesis). Universidad Nacional Autónoma de México, México.

Caso, M.E. (1962). Estudios sobre equinodermos de México. Contribución al conocimiento de los equinodermos de las islas Revillagigedo. Anales del Instituto de Biología. Universidad Nacional Autónoma de México, 33(1-2), 293-330. 
Caso, M.E. (1976). El estado actual del estudio de los equinodermos de México. Anales del Centro de Ciencias del Mar y Limnología, Universidad Nacional Autónoma de México, 3(1), 1-56.

Caso, M.E. (1978). Los equinoideos del Pacífico de México. Parte 1. Órdenes Cidaroidea y Auldonta. Parte 2. Órdenes Stiridonta y Camarodonta. Anales del Centro de Ciencias del Mar y Limnología, Universidad Nacional Autónoma de México, Publicación especial,1, 1-244.

Clark, A.H. (1939). Echinoderms (others than Holothurians). Smithsonian Miscellaneous Collections, 98(1), $1-18$.

Clark, A.H. (1946). Echinoderms from the Pearl Islands. Bay of Panamá with a revision of the Pacific Species. Smithsonian Miscellaneous Collections, 106(5), 1-11.

Clark, H.L. (1902). Papers from Hopkins Stanford Galapagos expedition, 1898-1899.XII. Echinodermata. Proceedings of the Whashington Academy of Sciences, 4, 521-531.

Clark, H.L. (1907). The Cidaridae. Bulletin of the Museum of Comparative Zöology. Harvard College, 51(7), 165-228.

Clark, H.L. (1913). Echinoderms from Lower California, with descriptions of new species. Museum of Comparative Zöology at Harvard College, 32, 185-236.

Clark, H.L. (1923). Echinoderms from Lower California with descriptions of new species. Supplementary report. Bulletin of the Museum of Comparative Zoölogy at Harvard College, 48(6), 147-163.

Clark, H.L. (1940). Notes on Echinoderms from the West Coast of Central America. Zoologica, 25, 331-352.

Clark, H.L. (1948). A report on the Echini of the warmer Eastern Pacific, based on the collections of the "Velero III". Allan Hancock Pacific Expeditions, 8, 225-351.

Conejeros-Vargas, C.A. (2015). Taxonomía y distribución de los equinodermos (Echinodermata) de las costas de Michoacán, México (Bachelor thesis).Universidad Nacional Autónoma de México, México.

Coppard, S.E., Kroh, A., \& Smith, A.B. (2012). The evolution of pedicellariae in echinoids: an arms race against pests and parasites. Acta Zoologica (Stockholm), 93, 125-148.

Döderlein, L. (1887). Japanischen Seeigel. Stuttgart E. Schweizerlart'sche Verlagshandlung.
Ebert, T.A. (1988). Growth, Regeneration, and Damage Repair of Spines of the Slate-Pencil Sea Urchin Heterocentrotus mammillatus (L.) (Echinodermata: Echinoidea). Pacific Science, 42, 160-172.

Lamarck, J. B. M. (1816). Histoire naturelle des animaux sans vertèbres, Tome troisième (Histoire naturelle des animaux sans vertèbres présentant les caractéres généraux et particuliers de ces animaux, leur distribution, leurs classes, leurs familles, leurs genres, et la citation des principales espèces qui s'y rapportent). Paris: Deterville/Verdière.

Leske, N.G. (1778). Iacobi Theodori Klein Naturalem dispositionim echinodermatum. Accesserunt Lucubratiuncula de aculeis echinorum marinorum et spicilegium de belemnitis edita et descriptionibus novisque inventis et synonomis auctorem aucta. Ex Officina Gleditschiana, Lipsiae, 23, 1-278.

Lessios, H.A., Kessing, B.D., Robertson, D.R., \& Paulay, G. (1999). Phylogeography of the pantropical sea urchin Eucidaris in relation to land barriers and ocean currents. Evolution, 53(3), 806-817.

Lockington, W.N. (1875-1876). List of Echinidae now in the collection of the California Academy. Proceedings of the California Academy of Sciences, 6, 152-159.

Maluf, L.Y. (1988). Composition and distribution of the central Eastern Pacific Echinoderms. Natural History Museum of Los Angeles County Technical Reports, 2, 1-242.

Mortensen, H.T. (1921). Studies of the development and larval of Echinoderms. Copenhagen: C.A. Rietzel Publisher.

Mortensen, H.T. (1928). A monograph of the Echinoidea I. Cidaroidea. Copenhagen: C.A. Rietzel Publisher, Oxford University press.

Mortensen, H.T. (1950). Reports of the BANZAR Antarctic Research Expedition 1929-1931: Echinoidea. The BANZAR Expedition Committee, Adelaide. 4(10), 287-309.

Pomel, M.A. (1883). Clasificación metódica y genérica de los equinoideos vivos y fósiles (Doctoral thesis). Academia de Paris, France.

Ziesenhenne, F.C. (1937). The Templeton Crocker Expedition. Echinoderms from the West Coast of Lower California, the Gulf of California and Clarion Island. Zoologica, 22(3), 209-239. 